\title{
Health hazards as a consequence of the poor technical condition of vehicles in Ghana
}

\author{
Katarzyna Wojtysiak $^{1^{*}}$, Ewa Zieliński ${ }^{2}$ Tomasz Wojsz ${ }^{3}$ \\ ${ }^{1 *}$ Department of Social and Medical Sciences, Faculty of Health Sciences, Collegium Medicum in Bydgoszcz of the \\ Nicolaus Copernicus University in Torun, Poland; ${ }^{2}$ Department of Emergency Medicine, Faculty of Health Sciences \\ Collegium Medicum in Bydgoszcz of the Nicolaus Copernicus University in Toruń, Poland; ${ }^{3}$ Student, University of \\ Bialystok, Poland. \\ Email: *katarzyna.sas@ hotmail.pl
}

\section{Keywords}

Health Hazards, Technical Condition, Vehicles,

Accidents, Developing Countries, Ghana.

\section{Article History}

Received on $8^{\text {th }}$ September 2021

Accepted on $19^{\text {th }}$ September 2021

Published on $24^{\text {th }}$ September 2021

\section{Cite this article}

Wojtysiak, K., Zieliński, E., \& Wojsz, T. (2021).

Health hazards as a consequence of the poor

technical condition of vehicles in Ghana.

Humanities \& Social Sciences Reviews, 9(5), 47-

50. https://doi.org/10.18510/hssr.2021.957

\section{Copyright @Author}

Publishing License

This work is licensed under a Creative Commons Attribution-Share Alike 4.0 International License

\section{Abstract}

Purpose: This is a review to assess the health hazards resulted from the poor technical condition of vehicles in Ghana. In developing countries, the number of vehicles involved in road traffic is systematically increasing. The health consequences of road accidents are a crucial public concern.

Methodology: The PubMed and Google scholar search were used to find literature for this analysis. The following keywords were taken into consideration in this paper: health hazards, technical conditions, vehicles, accidents, developing countries, Ghana. The analysis has been done by the systematic review analysis method. The articles were selected in terms of the health hazards resulting from the poor technical condition of vehicles in Ghana and its effects on road safety. Twenty papers were being reviewed.

Main findings: The quality of vehicles on Ghanaian roads is low. Most of the cars are old. For economic reasons, users often use substandard products to repair cars. Poor-quality, non-original, mismatched parts can lead to an accident. The technical condition of vehicles affects the safety of road users. The security of citizens should be an essential goal of the state. Inspections of the technical condition of cars, especially in public transport, should be strengthened and the frequency increased.

Implications: Based on the analysis of the publications, it was assessed that there is no current literature on technical problems of vehicles in Ghana, with particular emphasis on public transport. This is an essential topic for the security of citizens and should be investigated, analyzed, and lessons learned without delay.

Novelty in this study: There is a lack of systematic reviews of the impact of health hazards resulted from the poor condition of vehicles in Ghana. The paper is an attempt to assess the impact of the problem.

\section{INTRODUCTION}

In developing countries, the number of vehicles involved in road traffic is systematically increasing. According to the International Organization of Motor Vehicle Manufacturers, 890,000 cars were registered in Ghana in 2015 and this number has been growing since 2010 (CEIC Data Website: Https://Www.Ceicdata.Com/En/Indicator/Ghana/MotorVehicle-Registered [Access: 05.07.2021].). However, the technical condition of the cars is not satisfactory. The situation is particularly worrying on this continent due to a combination of poor vehicle conditions, underdeveloped road infrastructure, a lack of risk awareness among road users, and ineffective enforcement due to corruption or bribery (Lagarde, 2007). Mainly used vehicles imported from developing countries are in road traffic, especially in the villages and poor areas of the cities. Ackah estimates that in 2005-2007 only 9\% of vehicles were in good technical condition (Ackaah \& Adonteng, 2011). The technical condition of cars affects the safety of road users. With the start of the globalization process, Ghana gradually enters the second phase of the epidemiological transformation, which means a gradual reduction in the percentage of victims of infectious diseases in favour of the rate of accident victims in the total mortality. As the number of vehicles increases, the percentage of road accidents and road accident victims also increases. Mock's research indicates that transport-related injuries were more severe than other types of damages in terms of mortality, length of disability, and economic consequences (C. N. Mock et al., 1999).

\section{PURPOSE OF THE RESEARCH}

This is a review to assess the technical condition of vehicles in developing countries and its impact on health hazards in the example of Ghana. 


\section{METHODOLOGY}

The PubMed and Google scholar search was used to find literature to analyze the purpose of the paper. The following keywords were searched for information sources: health hazards, technical conditions, vehicles, accidents, developing countries, Ghana. Articles were selected according to the technical state of vehicles in developing countries and health hazards in developing countries, on the example of Ghana. The analysis has been done by the systematic review analysis method. The articles were selected in terms of the impact of poor technical condition of vehicles in Ghana and its effects on road safety in this area. Twenty papers were being reviewed.

\section{REVIEW ANALYSIS / DISCUSSION}

\section{Vehicles condition in ghana}

Due to the increasing number of vehicles in Ghana, their technical condition is an increasingly important problem. This problem does not only include private vehicles. Both the tro, i.e. private minibusses that run on fixed routes departing when full, and local taxis have visible features that threaten public safety. The most common causes of accidents resulting from technical faults are damaged lighting, malfunctioning braking system, inadequate tires, problems with the steering system, and other damage requiring repair (Wojtas \& Szkoda, 2018). The quality of vehicles on West African roads is low. For economic reasons, users often use substandard products. Poor-quality, non-original, mismatched parts can lead to an accident. Factors that may contribute to an accident in African countries include brake failure, tire burst, engine failure, defective and blinding lights, or the use of counterfeit spare parts (Oluwaseyi Joseph Afolabi \& $\mathrm{T}$ Gbadamosi Kolawole, 2017).

In the context of the handover of used vehicles, there are links between Europe and Africa. As part of the development and humanitarian aid, used cars are delivered to the African market, where they often function in a changed role for years. An example is the transformation of a German ambulance into a Ghanaian Trootro vehicle for public transport (Beisel \& Schneider, 2012). The technical condition of vehicles in Ghana is questionable. There are heavily corroded vehicles on the roads, with unprotected, visible cracks in the windows, inoperative lights, or large holes in the chassis. Often you can see doors that are not closing properly, which are tied to ensure the safety of passengers. These problems are visible. Alhassan research shows that using old cars increases the risk of an accident. For each year, the chance of an accident grows by $23.6 \%$ (Alhassan et al., 2018).

In developing countries, vehicles are kept in poor condition due to financial reasons, lack of awareness, and lack of appropriate competencies among road safety control workers (Eke, 2001). In particular, in rural areas and poorer parts of cities, it can be observed that repairs are made only if the can requires it due to the impossibility of fulfilling the basic role of the vehicle. The best example is the tyre. Drivers do not change them until holes appear. Unfortunately, the Edunyh study found four leading causes of tire failure: excessive and under-inflation, excessive wear, and overload of vehicles. More than $89 \%$ of drivers are unaware of tire safety measurements, especially the legal requirement for a minimum tire tread depth in force in Ghana (Edunyah, 2016). For every $1 \mathrm{~mm}$ decrease in the tyre's tread depth, the accident probability increases by about $40 \%$ (Alhassan et al., 2018) Not all road users take a responsible approach to ensuring road safety.

It should be remembered that the road user is responsible not only for his safety but also for the protection of other users. Technical inspection at a vehicle inspection station serves both as control and disciplines the user to make the necessary repairs. Therefore, the implementation of the obligation to perform periodic technical inspections would affect the elimination of inoperative vehicles from road traffic and increase the safety of users (Pałubicki \& Czapiewski, 2017). Delays in carrying out the necessary repairs or changes endanger the safety of users. Therefore, special attention should be paid to the inspection of vehicles, in particular cars carrying passengers in public transport.

\section{Road safety in public transport}

In countries like Ghana private vehicles are very rare, and people from villages mostly use public transport (Afukaar et al., 2019). In developed countries, most public transport is provided by public institutions. However, in developing countries, transport is mainly offered by private companies which work under highly competitive but poorly regulated conditions what can risk the safety of the passengers (Agyeman, 2013).

In the North of Ghana motorised, three-wheel vehicles are the third most frequently used mode of transport, especially for people with low and middle income. This mode of transport users is less protected in case of a traffic crash (Wahab

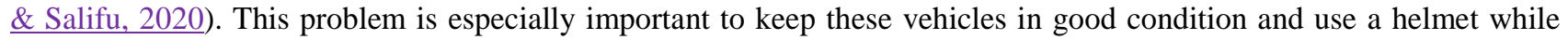
driving. Also, using a seat belt reduces the risk of severe injury or death during an accident. Ghana has mandatory seat belt laws; however, not many of the users respect it (Teye-Kwadjo et al., 2020) According to Ojo, 53.1\% of drivers did not use the seat belt (Ojo, 2018). In local transport, most of the tros operating in the urban area does not provide the possibility to use a seat belt for each user what poses a risk for passengers in case of sudden braking or accident.

\section{Health hazards resulted from the poor technical condition}

Although non-communicable diseases are still the leading causes of death outside the hospital, most of the deaths are due to road traffic accidents, and these numbers are systematically increasing (Akakpo et al., 2020) Research suggests that road traffic accidents cause 16\% of injuries in urban areas and 10\% in rural areas (C. N. Mock et al., 1999). Ametefe indicates that $70.3 \%$ of spinal injuries at Korle Bu Teaching Hospital are caused by road accidents, especially in young 
men (Ametefe et al., 2016). Spinal injuries are the most dangerous consequences of road accidents. Unfortunately, no statistics are available about other health consequences of road accidents in this region.

Ackaah points out that excessive vehicle speed, an inadequate adaptation of vans to transport people in tros, overloading, and the lack of a properly functioning emergency medical care system are the leading causes of high road death rates (Ackaah \& Adonteng, 2011). Mock's research shows that a significant proportion of accidents involve public transport, $40 \%$ of accidents involve buses, and $24 \%$ of taxis (C. Mock et al., 1999). It shows that road safety also depends on public transport. It is important to note that the age and condition of the vehicles is one of the most important factors of survival on the road, drivers whose vehicles aged over ten years had lower survival chances than those with vehicles less than ten years(Alhassan et al., 2018). Interestingly, the risk of death in a traffic accident at night is 1.3 times higher than during the daytime (Ackaah et al., 2020) As accidents risk the life of road users, all efforts should be made to reduce their number and thus increase the safety of users

\section{LIMITATIONS}

In developing countries, not all road accidents are reported. The article is based only on published information and literature data.

\section{IMPLICATIONS}

Based on the analysis of the publications, it was assessed that there is no current literature on technical problems of vehicles in Ghana and their impact on road safety, with particular emphasis on public transport. This is an essential topic for the security of citizens and should be investigated, analyzed and lessons learned without delay.

\section{CONCLUSIONS}

The security of citizens should be an essential goal of the state. It is important to emphasize seat belts role in ensuring the safety of vehicle passengers. Inspections of the technical condition of vehicles, especially in public transport, should be strengthened and the frequency increased. Restrictions concerning the poor technical condition of the car should be strongly enforced to improve the safety of Ghanaian citizens.

\section{CONTRIBUTION}

Paper conception and design: K. Wojtysiak (33,33\%), T. Wojsz (33,33\%), E. Zieliński (33,33\%).

Data collection: K. Wojtysiak (33,33\%), T. Wojsz (33,33\%), E. Zieliński (33,33\%).

Manuscript preparation: K. Wojtysiak (33,33\%), T. Wojsz (33,33\%), E. Zieliński (33,33\%).

All authors reviewed the results and approved the final version of the manuscript.

\section{DISCLOSURE}

The authors report no conflicts of interest in this work.

\section{REFERENCES}

1. Ackaah, W., \& Adonteng, D. O. (2011). Analysis of fatal road traffic crashes in Ghana. International Journal of Injury Control and Safety Promotion, 18(1), 21-27. https://doi.org/10.1080/17457300.2010.487157

2. Ackaah, W., Apuseyine, B. A., \& Afukaar, F. K. (2020). Road traffic crashes at night-time: characteristics and risk factors. International Journal of Injury Control and Safety Promotion, 27(3), 392-399. https://doi.org/10.1080/17457300.2020.1785508

3. Afukaar, F., Damsere-Derry, J., Peters, K., \& Starkey, P. (2019). Rural Transport Services Indicators: Using a new mixed-methods methodology to inform policy in Ghana. Transportation Research Interdisciplinary Perspectives, 3, 100074. https://doi.org/10.1016/j.trip.2019.100074

4. Agyeman, W. (2013). Measurement of service quality of "Trotro" as public transportation in Ghana: A case study of the city of Kumasi. 32nd Southern African Transport Conference (SATC 2013).

5. Akakpo, P. K., Imbeah, E. G., Agyarko-Wiredu, F., Awlavi, K., Baah-Amoh, K., \& Derkyi-Kwarteng, L. (2020). Community Causes of Death in the Central Region of Ghana, the Missing Piece in Mortality Data. Advances in Public Health, 2020, 2714616. https://doi.org/10.1155/2020/2714616

6. Alhassan, F., Mamadou, L. D., \& Katara, S. (2018). Survival modeling of accident risks of vehicle drivers in Northern Region of Ghana. Scientific Research and Essays, 13(4), 27-43. https://doi.org/10.5897/sre2017.6549

7. Ametefe, M. K., Bankah, P. E., Yankey, K. P., Akoto, H., Janney, D., \& Dakurah, T. K. (2016). Spinal cord and spine trauma in a large teaching hospital in Ghana. Spinal Cord, 54(12), 1164-1168. https://doi.org/10.1038/sc.2016.57

8. Beisel, U., \& Schneider, T. (2012). Provincialising waste: The transformation of ambulance car 7/83-2 to tro-tro Dr.Jesus. Environment and Planning D: Society and Space, 30(4), 639-654. https://doi.org/10.1068/d9610

9. CEIC data website: https://www.ceicdata.com/en/indicator/ghana/motor-vehicle-registered [access: 05.07.2021].

10. Edunyah, I. (2016). Causes of Tyre failure on Road Traffic Accident; A case study of Takoradi Township. International Journal of Scientific and Research Publications, 6(2), 30-35.

11. Eke, N. (2001). Road traffic accidents in the developing world: Who are liable? Anil Aggrawal's Internet 
Journal of Forensic Medicine and Toxicology, 2(1), 14.

12. Lagarde, E. (2007). Road traffic injury is an escalating burden in Africa and deserves proportionate research efforts. PLoS Medicine, 4(6), 170. https://doi.org/10.1371/journal.pmed.0040170

13. Mock, C. N., Forjuoh, S. N., \& Rivara, F. P. (1999). Epidemiology of transport-related injuries in Ghana. Accident Analysis and Prevention, 31(4), 359-370. https://doi.org/10.1016/S0001-4575(98)00064-5

14. Mock, C., Amegashie, J., \& Darteh, K. (1999). Role of commercial drivers in motor vehicle related injuries in Ghana. Injury Prevention, 5(4), 268-271. https://doi.org/10.1136/ip.5.4.268

15. Ojo, T. K. (2018). Seat belt and child restraint use in a developing country metropolitan city. Accident Analysis and Prevention, 113, 325-329. https://doi.org/10.1016/j.aap.2018.02.008

16. Oluwaseyi Joseph Afolabi, \& T Gbadamosi Kolawole. (2017). Road Traffic Crashes in Nigeria: Causes and Consequences. International Journal of Shipping and Transport Logistics, 17(42), 2406-2469.

17. Pałubicki, S., \& Czapiewski, W. (2017). Wpływ okresowych badań technicznych na bezpieczeństwo ruchu drogowego [The impact of cyclic technical research on road safety]. Autobusy: Technika, Eksploatacja, Systemy Transportowe [Buses: Technology, Operation, Transport Systems], 18, 87-92.

18. Teye-Kwadjo, E., Salia, S., Mensah, G. O., \& Ofori, R. (2020). Exploring Ghanaian commercial drivers' intentions to wear a seat belt. Case Studies on Transport Policy, 8(2), 453-459. https://doi.org/10.1016/j.cstp.2019.10.009

19. Wahab, L., \& Salifu, M. (2020). Operational and Safety Assessment of Motorised Three-Wheel Vehicles for Public Transport in the Tamale Metropolis. International Journal of Technology and Management Research, 2(1), 26-35. https://doi.org/10.47127/ijtmr.v2i1.48

20. Wojtas, A., \& Szkoda, M. (2018). Analysis of selected factors influencing safety in road transport. Autobusy Technika, Eksploatacja, Systemy Transportowe [Buses: Technology, Operation, Transport Systems], 19(6), 1149-1154. https://doi.org/10.24136/atest.2018.244 